\title{
Tentang Sejarah Surau di Minangkabau
}

DOI 10.18196/AIIJIS.2017.0077.283-287

\section{IKHSAN HAKIM}

Universitas Muhammadiyah Yogyakarta

$\begin{array}{ll}\text { Judul } & : \text { Tiga Sepilin Surau Solusi Untuk Bangsa } \\ \text { Penulis } & \text { : Mas'aoed Abidin } \\ \text { Penerbit } & : \text { Cv. Gre Publishing } \\ \text { Kota } & : \text { Yogyakarta } \\ \text { Tahun } & : 2016 \\ \text { Halaman } & : 532 \\ \text { ISBN } & : 978-602-7677-90-6\end{array}$

Surau adalah suatu lembaga pendidikan Islam terkenal di Indonesia. Berasal dari Sumatera Barat khas Minangkabau. Satu karya yang muncul dalam kajian lembaga pendidikan Islam Indonesia adalah ditulis oleh $\mathrm{H}$. Mas'oed Abidin, seorang ulama Minangkabau yang masih hidup. Buku memaparkan Surau sebagai lembaga pendidikan Islam di Sumatera Barat yang bisa mencetak ulama-ulama besar Indonesia. Menggambarkan dinamika surau, dimulai dari kemunculan, tokoh-tokoh pengembangnya, kontribusi dalam pembentukan masyarakat Minangkabau dan mewarnai Islam di Indonesia pada awal abad ke XIX.

Secara umum buku ini menggambarkan proses pembentukan surau dan keinginan untuk kembali menjadikan surau sebagai pembentuk kemunculan ulama-ulama sebagaimana di masa kejayaannya. Buku ini adalah gabungan dari tiga buku yaitu Surau Kito. Halakah Surau, Suluah Bendang Dalam Nagari dijadikan satu buku dengan judul Tiga Sepilin Surau Solusi Untuk Bangsa. Buku ini turut menyumbang literature baru dalam jaringan ulama Nusantara. Penulis H. Mas'oed Abidin, bermaksud membangun kembali kejayaan surau dibangun di atas falsafah adat basandi syarak, syarak basandi kitabullah disingkat ABS-SBK. Penulis juga memaparkan konsep, materi pembelajarannya dan tujuan pembelajaran menurut surau versi masa kini karena tidak dimungkinkan lagi menciptakan 
surau sebagaimana dulu kemunculannya disebabkan perubahan zaman dan masyarakat Minangkabau yang hidup di masa abad XXI.

Buku pertama, dibagi menjadi 9 bagian. Pada bagian pertama memaparkan makna surau sebagai tempat umat belajar mengaji, sarana pendidikan atau madrasah tarbiyah bagi anak nagari di ranah Minangkabau. Minangkabau memiliki dua lembaga penopang adat basandi syarak, sayarak basandi kitabullah yaitu surau dan balairung (balai ruang yang tidak memiliki kamar sama halnya dengan surau). Bagian kedua, menerangkan adanya pergeseran nilai di masyarakat dan solusinya. Maka perlu pembaharuan terus menerus dengan semangat baru dan kemasan baru Bagian ketiga, memaparkan surau sebagai lembaga pendidikan alternative. Pada awalnya eksistensi surau menemukan bentuknya di tangan Syekh Burhanuddin murid dari Syekh Abdurrauf Singkil mendirikan Surau Ulakan, Pariaman. Dilanjutkan oleh muridnya Tuanku Mansiang Nan Tuo mendirikan Surau Paninjauan dan Tuanku Nan Kacik yang mendirikan surau di Kotagadang Agam. Seterusnya dua surau ini menghasilkan ulama-ulama di Minangkabau. Jalur keilmuan ulama Minangkabau ini sangat memberikan kontribusi besar dalam penyebaran agama Islam di Sumatera Barat. Bagian keempat, penulis memaparkan ajakan untuk menjadikan kembali surau sebagai perguruan membina anak nagari. Minangkabau dalam sejarah tidak terlepas dengan lembaga surau, karena nostalgia akan kejayaan masa lalu, perbedaan dengan masa sekarang kebanyakan surau hanya berfungsi sebagai tempat sholat saja. Bagian kelima, memaparkan untuk menghidupkan kembali ukhuwah Islamiyah. Persatuan yang didengungkan dari dahulu tetap mengalami penggerusan, maka harus terus disosialisasikan. Walaupun pada kenyaatannya hanya sebatas pertemuan, belum membuminya untuk kerjasama kongkrit antar ormas atau antar paham, kecuali bergerak sendirisendiri. Bagian keenam, memaparkan terjadinya kemiskinan disebabkan menyusutnya penguasaan atas kepemilikan tanah untuk orang Minangkabau dan solusinya. Juga memaparkan falsafah pengelolaan tanah dalam budaya Minang. Kemiskinan akan sumber penghidupan karena akibat harga dipasaran yang rendah dan kurangnya kreativitas sering dialami daerah-daerah pelosok di Indonesia. Bagian ketujuh, mengajak manusia untuk mengagungkan Asma Allah. Kepercayaan akan adanya Penguasa alam semesta membawa kita kepada kesyukuran sebagaimana menjadi keyakinan agama-agama bahwa pengagungan kepada Tuhan 
adalah suatu jalan peribadatan. Bagian kedelapan, mengajak untuk mempersiapkan generasi yang akan datang. Persiapan akan generasi yang berkualitas adalah suatu keniscayaan untuk keberlangsungan peradaban. Generasi yang lemah dan tidak produktif adalah generasi menjadi beban sejarah, akhir dari semuanya adalah menciptkan penindasan oleh pihak yang lebih kuat, kalau meminjam pendekatan Darwinisme. Bagian kesembilan, memaparkan nilai-nilai pendidikan surau. Banyak orang yang tidak mengetahui lebih mendalam tentang surau, bahkan ada yang menganggap sebatas bangunan masjid khas arsitektur Sumatera Barat. Tapi penulis memberikan gambaran yang lumayan lengkap tentang nilainilai surau di masa lalu dan akan dihidupkan kembali diama sekarang dengan muatan baru. Yang menarik dari buku pertama ini adalah transmisi keilmuan ulama Minagkabau sebagai tokoh sentral surau dari bercorak tarekat di bawah Tuanku sebutan untuk ulama besar. Kekhasan surau juga di samping sebagai tempat mencari ilmu dan otoritas keilmuannya menggeser dominasi para penghulu adat sebagai tempat orang bertanya untuk menyelasaikan persoalan.

Buku kedua, terdiri dari 9 bagian. Bagian pertama, memaparkan masuknya Islam ke Minangkabau yang dibagi menjadi dua pendapat yaitu pertama melalui pesisir timur Minangkabau pada abad ke 13 pada saat kerajaan Samudra Pasai menguasai jalur perdagangan. Kedua, melalui pantai barat sumatera pada abad ke 16 sebagai akibat kejatuhan Malaka kepada Portugis. Dan menerangkan dua penemuan naskah masuknya Islam ke Minangkabau yaitu Naskah Muballighul Islam tahun 1184 dan Naskah Ulakan, naskan ini memaparkan kontribusi Syek Burhanuddin sebagai ikut peletak dalam pembentukan falsafah adat basandi syarak, syarak basandi kitabullah di Istana Pagaruyung. Pada awal abad ke20 penulis memaparkan bahwa surau sebagi tempat gerakan pembaharuan Islam di Minangkabau, berbeda dengan abad ke 16 surau yang bercorak tarekat. Bagian kedua, penulis melanjutkan bahwa syarak (syariat Islam) dimulai dari nasehat dan akan menemukan bentuknya di dalam adat. Adat yang dikenal sekarang di Minagkabau adalah proses yang sudah lama berjalan dan menemukan kesempurnaanya seiring bertambahnya waktu. Bagian ketiga, tauhid sebagai sumber kekuatan di Minangkabau, penulis mencontohkan rapat besar Majelis Permusyawaratan Ulama Minangkabau 19 agustus 1928 yang menelorkan mosi menolak Guru Ordonansi 1925. Menggambarkan kuatnya ikatan tungku tigo sajarangan 
yaitu ninik mamak, cerdik pandai dan alim ulama, karena setiap bagian hadir menandatagani hal tersebut. Bagian keempat, penulis melanjutkan perlunya tazkiyatun nafs atau pembersihan diri. Hal ini adalah salah satu terma dalam khazanah keilmuan Islam yaitu pembersihan batin dan kalbu dari segala penyakit-penyakitnya dan cara penyembuhannya. Mengalami kristalisasi di golongan ahli tasawuf dengan disistemkan yang diwakili oleh tarekat-tarekat. Bagian kelima, pentingnya tuntunan akhlak. Akhlak adalah cerminan iman seseorang, penyebaran Islam tidak bisa lepas dari keluhuran moral yang ditunjukkannya. Menjadi penting ketika menundukkan hati para suku atau daerah-daerah yang keras perangainya. Bagian keenam, sambungan dari bab sebelumnya tujuan akhlak untuk membangun peradaban, bahwa kesinambungan peradaban harus ditopang dengan akhlak. Keruntuhan akan peradaban berawal dari rusaknya individu-individu, rusaknya individu berakibat rusaknya masyarakat. Bagian ketujuh, Pendidikan surau, penulis membuat silabus surau untuk para guru/muallim dalam penjiwaan ABS-BSK. Di sinilah terbosan yang ditawarkan penulis, dahulu surau tergantung kepada sosok seorang tokoh. Di zaman ini metode yang bisa diduplikat dan dicopy bisa menjadi alternative bagus untuk menghidupkan surau dan meraih kejayaannya kembali. Bagian kedelapan lebih mendetail, penulis memaparkan silabus halakah surau yaitu alokasi waktu dan teknis pembelajaran di lapangan. Ini adalah suatu terobosan besar untuk Bagian kesembilan, penjelasan mengenai kurikulum dalam pendidikan halakah surau, materi pembalajarannya. Proses belajar mengajar tidak terlepas dari hal ini, penulis memaparkan urgensinya akan hal ini. Yang menarik dari buku yang kedua ini adalah sudah mengkerucut gagasan penulis tentang pembentukan surau versi sekarang. Baik dari segi kurikulum, alokasi waktu pembelajaran maupun materi pembelajaran.

Buku ketiga, terdiri dari 9 bagian. Bagian pertama, memaparkan bahwa adanya perubahan prilaku masyarakat yang berorientasi kepada materi dan perlu pembentukan generasi unggul. Salah satu instrument surau adalah tabuah berfungsi mengumpulkan anak nagari sudah digantikan dengan pengeras suara artinya perubahan seperti ini tidak jadi masalah. Bagian kedua, menerangkan bahwa adat pepatah pepitih Minang bisa seirama dengan nilai-nilai agama dan masa kini. Hal ini Buya Hamka banyak menulis hal serupa, terkenal di buku dengan judul Ayahku. Bagian ketiga, penulis melanjutkan ciri utama kepribadian Imam Khatib Adat di Nagari, 
tentang jasmani maupun ruhani nya yang harus mereka miliki. Sesudah itu mereka akan menjadi suluah bendang. Suatu istilah khas Minagkabau, yang menempatkan orang pada starta sosial yang patut dihargai dan tempat mencari ilmu. Bagian keempat, penulis melanjutkan bahwa integrasi Islam dengan budaya Minangkabau mengalami perpaduan yang khas. Sehingga Adat tidak bertentangan dengan agama. Bagian kelima, mamaparkan persiapan ummat menghadapi masa depan. Penulis pada bagian ini lebih menekannkan mempersiapkan generasi, karena adanya kekhawatiran akan masa depan generasi Minangkabau. Bagian keenam, implementasi dan pelestarian ABS-SBK terlihat dalam Masyarakat Hukum Adat Minangkabau. Bagian ketujuh, membahas tentang tata ruang di Minangkabau diambil dari pepatah adat alias cara memperlakukan alam. Bagian kedelapan, pentingnya peran perempuan menurut perspektif ABSSBK. Bagian kesembilan, filsofis hidup Minang untuk sukses dunia akhirat. Yang menarik dari buku ini adalah adanya tolak ukur seorang Imam Khatib Adat di nagari dan tata ruang menurut falsafah dan budaya Minangkabau, sangat diperlukan untuk dijadikan inspirasi pembentukan masyarakat sekaligus tata ruang suatu negri. Menjadikan buku ini menjadi pelengkap dari seluruh tulisan tentang Surau di Minangkabau. Memberikan solusi dan gagasan baru yang bisa dipraktekkan oleh siapapun. Semangat inklusifitas terekam dalam buku ini. 